\title{
Original
}

\section{A high concentration of triiodothyronine attenuates the stimulatory effect on hemin-induced erythroid differentiation of human erythroleukemia K562 cells}

\author{
Mieno Shiraishi ${ }^{1)}$, Yoritsuna Yamamoto ${ }^{2)}$, Nobutaka Hirooka ${ }^{1)}$, Yasuhiro Obuchi ${ }^{1)}$, Shoichi Tachibana ${ }^{2)}$, \\ Makoto Makishima $^{3)}$ and Yuji Tanaka ${ }^{1)}$ \\ 1) Department of General Medicine, National Defense Medical College, Tokorozawa 359-8513, Japan \\ 2) Division of Environmental Medicine, National Defense Medical College Research Institute, National Defense Medical College, \\ Tokorozawa 359-8513, Japan \\ 3) Division of Biochemistry, Department of Biomedical Sciences, Nihon University School of Medicine, Tokyo 173-8610, Japan
}

\begin{abstract}
Although thyroid hormone is a known stimulator of erythropoietic differentiation, severe anemia is sometimes observed in patients with hyperthyroidism and this mechanism is not fully understood. The aim of this study was to investigate the effect of triiodothyronine (T3) on hemin-induced erythropoiesis. Human erythroleukemia K562 cells were used as an erythroid differentiation model. Cell differentiation was induced by hemin and the effect of pre-incubation with T3 (0.1 to $100 \mathrm{nM}$ ) was analyzed by measuring the benzidine-positive rate, hemoglobin content, CD71 expression (transferrin receptor), and mRNA expression for transcription factors related to erythropoiesis and thyroid hormone receptors (TRs). Hemin, a promoter of erythroid differentiation, increased the levels of mRNAs for TR $\alpha$, TR $\beta$, and retinoid $\mathrm{X}$ receptor $\alpha(\mathrm{RXR} \alpha)$, as well as those for nuclear factor-erythroid 2 (NFE2), GATA-binding protein 1 (GATA1) and GATA-binding protein 2 (GATA2). Lower concentrations of T3 had a stimulatory effect on hemin-induced hemoglobin production ( 1 and $10 \mathrm{nM}), C D 71$ expression $(0.1 \mathrm{nM})$, and $\alpha$-globin mRNA expression $(1 \mathrm{nM})$, while a higher concentration of T3 $(100 \mathrm{nM})$ abrogated the stimulatory effect on these parameters. T3 at $100 \mathrm{nM}$ did not affect cell viability and proliferation, suggesting that the abrogation of erythropoiesis enhancement was not due to toxicity. T3 at $100 \mathrm{nM}$ also significantly inhibited expression of GATA2 and RXR $\alpha$ mRNA, compared to $1 \mathrm{nM} \mathrm{T3}$. We conclude that a high concentration of $\mathrm{T} 3$ attenuates the classical stimulatory effect on erythropoiesis exerted by a low concentration of $\mathrm{T} 3$ in hemin-induced K562 cells.
\end{abstract}

Key words: Triiodothyronine (T3), K562 cells, Erythroid differentiation, Hemin, Thyroid hormone(s)

THYROID hormone stimulates erythropoiesis and clinical hypothyroidism is often complicated by reductions in red cell mass and total blood volume, and by normocytic normochromic anemia [1-4]. Clinically, bone marrow has been observed to show erythroid hyperplasia in patients with hyperthyroidism [5]. However, anemia is sometimes observed in patients with hyperthyroidism such as Graves' disease (GD). Some reports indicate that anemia associated with hyperthyroidism occurs in $10-22 \%$ of cases of non-treated hyperthyroidism, and that these cases recover well with treatment of

Submitted Sep. 13, 2014; Accepted Feb. 18, 2015 as EJ14-0427 Released online in J-STAGE as advance publication Mar. 16, 2015 Correspondence to: Yuji Tanaka, Department of General Medicine, National Defense Medical College, Namiki 3-2, Tokorozawa, Saitama, 359-8513, Japan. E-mail: yitanaka@ndmc.ac.jp hyperthyroidism [6, 7]. This type of anemia is found most often in patients with hyperthyroidism of unusual severity or prolonged duration [8].

Thyroid hormone has a direct positive action on bone marrow erythropoiesis in rats [9] and thyroid hormone receptor $\alpha(\mathrm{TR} \alpha)$ was found to be essential for regulating erythropoiesis in a study characterizing the phenotype of $\mathrm{TR}^{-/-}$mice [10]. Bauer et al. showed that thyroid hormone receptor functions as a developmental switch in erythroid differentiation and that T3 suffices to arrest proliferation and induce erythropoiesis [11]. However, the mechanisms underlying the association between anemia and hyperthyroidism are not completely clear.

The K562 cell line was established from the pleural effusion of a 53-year-old woman as the first human 
immortalized leukemia cell line [12]. K562 cells are widely used as a model for investigation of erythropoiesis and globin gene expression. Differentiation of these cells can be induced by chemical agents such as hemin, sodium butyrate, DMSO, and erythropoietin (Epo) [13-15]. Hemin is an iron-containing porphyrin that is the prosthetic moiety for a broad range of proteins involved in oxygen delivery and is used to treat acute porphyria and thalassemia intermedia [16]. Hemin is a relatively strong inducer of heme biosynthesis among various chemical inducers of erythroid differentiation of K562 cells [17, 18].

Recently, we found that an excess of T3 suppresses activin-induced differentiation in erythroleukemia K562 cells under hypoxia, and that GATA2 expression might be correlated with this effect [19]. In this study, we investigated whether T3 has an effect on hemininduced erythropoiesis in K562 cells, with the goal of elucidating the mechanism underlying anemia in hyperthyroidism.

\section{Materials and Methods}

Most of the following procedures have also been described elsewhere [19].

\section{Cell culture}

K562 cells were kindly provided by Prof. Kimura (Department of Hematology, National Defense Medical College, Japan). These cells were cultured in RPMI 1640 medium (Life Technologies, Carlsbad, CA) supplemented with $10 \%(\mathrm{v} / \mathrm{v})$ fetal bovine serum at $37^{\circ} \mathrm{C}$ in humidified air with $5 \% \mathrm{CO}_{2}$. Hemin (Sigma, St. Louis, MO) was prepared as a $5 \mathrm{mM}$ stock solution in $0.1 \mathrm{~N} \mathrm{NaOH}$ and stored in aliquots at $-20^{\circ} \mathrm{C}$. Hemin $(40 \mu \mathrm{M})$ was used for differentiation unless otherwise noted. Triiodothyronine (T3; Sigma) was prepared as a $1 \times 10^{-5} \mathrm{M}$ stock solution in $0.1 \mathrm{~N} \mathrm{NaOH}$ and stored in aliquots at $-20^{\circ} \mathrm{C}$. Dilutions were made in RPMI 1640 medium. Thompson et al. showed that the transcriptional activities of thyroid hormone receptors $\alpha$ and $\beta$ are dose dependent from 1 to $100 \mathrm{nM} \mathrm{T3} \mathrm{[20],} \mathrm{while}$ the threshold $\mathrm{T} 3$ concentration for non-genomic effects ranges from 0.1 to $30 \mathrm{nM}$ [21]. Therefore, 0.1 to 100 nM T3 was used for pre-incubation in most experiments in the study.

\section{Growth potential}

Cells were harvested at $5 \times 10^{4}$ cells $/ \mathrm{mL}$ in a $100 \mathrm{~mm}$ dish and $1 \mathrm{nM}$ and $100 \mathrm{nM}$ T3 or an equal amount of $0.1 \mathrm{~N} \mathrm{NaOH}$ as a negative control were added. At $48 \mathrm{~h}$ and $96 \mathrm{~h}$ after treatment, $10 \mu \mathrm{L}$ of medium containing cells was collected and mixed with $10 \mu \mathrm{L}$ of $0.4 \%$ trypan blue solution, after which the number of viable cells was determined using an automated cell counter (TC20, Bio-rad). At $48 \mathrm{~h}$ after determining the cell number, cells were resuspended in the medium and then replated at $5 \times 10^{4}$ cells $/ \mathrm{mL}$. To examine the influence of hemin, K562 cells were harvested at $2 \times 10^{5}$ cells $/ \mathrm{mL}$ in a 100 $\mathrm{mm}$ dish and $40 \mu \mathrm{M}$ hemin or an equal amount of $0.1 \mathrm{~N}$ $\mathrm{NaOH}$ was added in the cell culture. At $72 \mathrm{~h}$ after treatment, cell viability was determined using an automated cell counter based on trypan blue exclusion.

\section{Flow cytometry}

K562 cells were harvested and resuspended at $1 \times 10^{7}$ cells/mL in Dulbecco's phosphate buffered saline (DPBS). Erythroid cell differentiation was determined by expression of transferrin receptor (CD71) and glycophorin A (CD235a). Cells were incubated with murine-specific monoclonal antibodies directed against CD71 and CD235a. Antibodies were coupled to R-phycoerythrin or fluorescein isothiocyanate. All antibodies were purchased from eBioscience (San Diego, CA). The fluorescence intensity was analyzed using a Cytomics FC 500 instrument (Beckman Coulter, Brea, CA). Results were also recorded as mean fluorescence intensity (MFI), which represents the cell surface receptor density.

\section{Benzidine staining}

Benzidine staining was performed as previously described [22]. Briefly, cells $\left(2 \times 10^{4}\right)$ were seeded into each well of a 6 -well dish containing $2 \mathrm{~mL}$ of medium. After several conditioning steps, cells were harvested in $10 \mu \mathrm{L}$ DPBS. Benzidine dihydrochloride solution $(2 \mathrm{mg} / \mathrm{mL}$ in $0.5 \%$ acetic acid) containing $0.15 \%$ hydrogen peroxide was added directly to an equal volume $(10 \mu \mathrm{L})$ of the cell suspension and incubated at $37^{\circ} \mathrm{C}$ for $5 \mathrm{~min}$. Positively stained cells were counted under a microscope. Images were recorded with an Axio Imager A2 microscope (Carl Zeiss Microscopy, Oberkochen, Germany) equipped with an AxioCam cooled-charge-coupled device camera system operated with AxioVision software (Carl Zeiss Microscopy).

\section{Hemoglobin content}

Cells in each dish were collected and cell numbers 
were determined using an automated cell counter with trypan blue exclusion (TC-20, Bio-rad). After washing with DPBS twice, $5 \times 10^{6}$ cells were dissolved in $120 \mu \mathrm{L}$ of deionized distilled water. Hemoglobin content was measured using a QuantiChrom Hemoglobin Assay Kit (BioAssay Systems, Hayward, CA).

\section{RT-PCR and quantitative real-time RT-PCR}

For real-time RT-PCR, total RNA was isolated with Trizol ${ }^{\circledR}$ reagent (Life Technologies). cDNA was synthesized from $1 \mu \mathrm{g}$ total RNA using SuperScript VILO $^{\circledR}$ (Life Technologies). mRNA levels of various genes were analyzed by qRT-PCR using TaqMan ${ }^{\circledR}$ Gene Expression Assays (Applied Biosystems, Foster City, CA) with a 7500 Real-Time PCR System (Applied Biosystems). The relative RNA level of each target gene was normalized to the RNA level of peptidylprolyl isomerase A (PPIA; cyclophilin A) as an internal control.

\section{Statistical analysis}

Data with a normal distribution are expressed as means $\pm \mathrm{SD}$. Other data are expressed as the median $\left(1^{\text {st }}-3^{\text {rd }}\right.$ quartile). Statistical analysis was performed using JMP 10.0.0 (SAS Institute Inc.). Comparison between two groups was performed by Mann-Whitney $\mathrm{U}$ test. Three groups were compared using standard one-way ANOVA after establishment of normality in a Shapiro-Wilk test and equal dispersion by Bartlett test. $p<0.05$ was considered to be significant. A TukeyKramer test with Bonferroni correction was performed as a post hoc test. Data that were not normally distributed were evaluated using non-parametric analysis (median test or Kruskal Wallis test) followed by a post hoc test (Steel-Dwass test or Kruskal-Wallis test) with Bonferroni correction.

\section{Results}

\section{Characteristics of $\mathrm{K562}$ cells}

The expression levels of mRNAs for $\mathrm{TR} \alpha, \mathrm{TR} \beta$, and retinoid $\mathrm{X}$ receptor $\alpha(\mathrm{RXR} \alpha)$ in steady state K562 cells were analyzed using quantitative real-time RT-PCR (Fig. 1), based on our previous identification of these mRNAs in the cells [19]. Expression levels were normalized based on the level of cyclophilin A (PPIA) as an internal control. The expression level of RXR $\alpha$, which forms a heterodimer with TR and significantly enhances binding to thyroid hormone response elements (TREs), was higher than those of TR $\alpha$ and

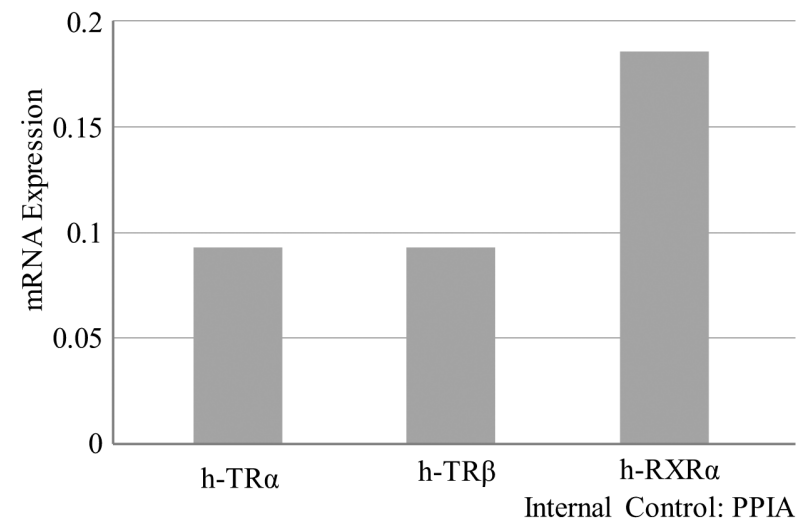

Fig. 1 Quantification of mRNA expression in steady state (untreated) K562 cells by quantitative real-time PCR for thyroid hormone receptor $\alpha(\mathrm{TR} \alpha)$, thyroid hormone receptor beta $(\mathrm{TR} \beta)$, and retinoid $\mathrm{X}$ receptor $(\mathrm{RXR} \alpha)$. PPIA was used as an internal control. All mRNAs were expressed in K562 cells.

TR $\beta$ in these cells.

Potentiation of K562 cells as erythroid progenitors was evaluated through addition of hemin in 100$\mathrm{mm}$ dishes, with an equal amount of $0.1 \mathrm{~N} \mathrm{NaOH}$ (the vehicle) used as a negative control. After exposure to hemin for $72 \mathrm{~h}$, the benzidine-positive rate was significantly higher in hemin-treated K562 cells compared to non-treated cells $(71.0 \%(70.25-74 \%) v s .1 .1 \%(0.9-$ $1.3 \%$ ), $p=0.032$; hemin: $n=4$, control: $n=3$ ), consistent with previous studies $[23,24]$. Hemoglobin levels per $5 \times 10^{6}$ cells after exposure to 10 to $50 \mu \mathrm{M}$ hemin for 72 $\mathrm{h}$ were elevated in a dose-dependent manner in K562 cells, with a significant difference at 40 and $50 \mu \mathrm{M}$ compared to control cells (Fig. 2A).

To analyze the influence of hemin on the cell proliferation rate and viability, cell counts were determined after hemin treatment. The cell count was significantly lower after exposure to $40 \mu \mathrm{M}$ hemin for $72 \mathrm{~h}$ compared to controls $\left(6.72 \pm 1.89 \times 10^{5} v s .13 .7 \pm 2.24 \times 10^{5}\right.$ $/ \mathrm{mL}$, (Table 1). Cell viability did not differ between cells with and without hemin exposure $(99.3 \pm 1.15 \%$ vs. $99 \pm 0.89 \%$ ). Expression of CD71 (transferrin receptor), which is required for iron delivery into cells, and CD235a (glycophorin a) were measured by flow cytometry. As shown in Table 2, cells were strongly positive for CD71 and rarely positive for CD235a. Treatment with $40 \mu \mathrm{M}$ hemin for $72 \mathrm{~h}$ did not change the MFI or the CD235a-positive rate, but increased the CD71positive rate, as seen in previous studies in K562 cells [17, 23-25].

To determine whether hemin-induced differentiation 
was detectable at the transcriptional level, mRNAs of erythroid transcription factors were measured by quantitative real-time RT-PCR. Exposure to hemin for $48 \mathrm{~h}$ significantly increased $\alpha$-globin, $\beta$-globin, GATA 1 , and NFE2 expression (Fig. 2B; $p<0.05$, hemin: $n=13$, control: $n=16$ ), as also found previously [26-28]. Because induction of $\alpha$-globin by hemin was significantly higher than that of $\beta$-globin, we used $\alpha$-globin as a molecular marker for erythroid differentiation in assessment of T3 action. Since GATA2 was also elevated, along with the globin genes, GATA1 and NFE2, GATA2 mRNA upregulation was used as a marker of erythropoiesis in hemin-treated K562 cells. Hemin also significantly augmented mRNAs for TR $\alpha, \operatorname{TR} \beta$ and RXR $\alpha$.

\section{Influence of T3 on proliferation of K562 cells}

To determine whether $\mathrm{T} 3$ affected cell proliferation, K562 cells were incubated in the absence or presence of $1 \mathrm{nM}$ or $100 \mathrm{nM} \mathrm{T} 3$ for up to $96 \mathrm{~h}$ and viable cells were counted. As shown in Fig. 3, T3 up to $100 \mathrm{nM}$ did not alter cell proliferation for at least $96 \mathrm{~h}$.

\section{Effects of T3 on hemin-induced differentiation of K562 cells}

The effect of T3 on the benzidine-positive rate in K562 cells was measured. Various concentrations of $\mathrm{T} 3$ and an equal amount of $0.1 \mathrm{~N} \mathrm{NaOH}$ as a negative control were added to cultures $24 \mathrm{~h}$ prior to hemin addition. The benzidine-positive rate of hemin-treated cells after $72 \mathrm{~h}$ was $71 \%(70.25-74 \%)$, and this was not significantly changed by T3 at $1 \mathrm{nM}(64.5 \%(61.25-$ $70 \%))$ or $100 \mathrm{nM}(67 \%(59.25-68.75 \%)(p=0.056, n=4$ in each group). Hemoglobin production was analyzed after various concentrations of T3 $(0.1-100 \mathrm{nM})$ and $0.1 \mathrm{~N} \mathrm{NaOH}$ as a negative control were added $24 \mathrm{~h}$ prior to hemin treatment. Hemoglobin production per $5 \times 10^{6}$ cells was measured after $72 \mathrm{~h}$ of hemin treatment. T3 at $1 \mathrm{nM}$ and $10 \mathrm{nM}$ significantly augmented hemin-induced hemoglobin production, while 100 nM T3 abrogated this stimulatory effect. Maximal enhancement was detected at $1 \mathrm{nM}$ T3 (Fig. 4A-1). Cell viability did not differ among hemin-treated cells exposed to various concentrations of T3, although cell proliferation with $1 \mathrm{nM}$ and $10 \mathrm{nM} \mathrm{T} 3$ was significantly decreased compared to cells without T3 (Fig. 4A-2). Because $1 \mathrm{nM}$ and $10 \mathrm{nM}$ T3 had inducible effects on hemoglobin production, we examined whether T3 itself can stimulate hemoglobin production. However, K562 cells treated with $1 \mathrm{nM}$ or $10 \mathrm{nM} \mathrm{T} 3$ for $72 \mathrm{~h}$ did not have increased hemoglobin content (Fig. 4A-3).

The MFI and rate of CD71 expression were maximally and significantly enhanced in hemin-treated K562 cells with $0.1 \mathrm{nM} \mathrm{T3}$ pre-incubation, while this stimulation was attenuated by 1-100 nM T3 (Fig. 4B). There was no significant difference in CD235a expression in hemin-treated K562 cells with or without T3 (data not shown).

Finally, mRNA expression was examined in hemintreated K562 cells with pre-incubation with 0,1 or $100 \mathrm{nM} \mathrm{T} 3$ for $24 \mathrm{~h}$ ( $n=7$ per group). Cells were collected after $48 \mathrm{~h}$ of hemin exposure. T3 had a significant stimulatory effect on $\alpha$-globin mRNA expression at $1 \mathrm{nM} \mathrm{T} 3$ compared to control (hemin $(+))$, and this effect was abrogated at $100 \mathrm{nM}$ T3. GATA2 expression in cells pretreated with $100 \mathrm{nM}$ T3 was significantly lower than that in cells pretreated with $1 \mathrm{nM}$ T3. The RXR $\alpha$ expression level in cells pretreated with 100 nM T3 was also significantly lower than that in cells pretreated with $1 \mathrm{nM} \mathrm{T3}$ (Fig. 4C).

\section{Discussion}

In this study, we demonstrated that a high concentration of T3 attenuates the stimulatory effect of T3 on hemin-induced erythropoiesis at lower concentrations in $\mathrm{K} 562$ cells. We also showed for the first time that hemin increases mRNA for TR $\alpha, T R \beta$, and RXR $\alpha$. T3 augmented hemin-induced hemoglobin production (1 and $10 \mathrm{nM}), \mathrm{CD} 71$ expression $(0.1 \mathrm{nM})$, and $\alpha$-globin mRNA expression $(1 \mathrm{nM})$, while this augmentation was abrogated at a higher T3 concentration of $100 \mathrm{nM}$.

Hemin induced hemoglobin production and decreased cell proliferation without cell death. T3 at a lower concentration augmented hemin-induced hemoglobin production with decreased cell proliferation without changing cell viability. T3 alone at $100 \mathrm{nM}$ did not alter cell proliferation, and 1 and $10 \mathrm{nM}$ T3 did not cause hemoglobin production, suggesting that $100 \mathrm{nM}$ $\mathrm{T} 3$ was not toxic, and that 1 and $10 \mathrm{nM} \mathrm{T} 3$ did not have erythropoietic effects in this culture. Hemin also significantly decreased cell proliferation. Collectively, these data indicate that lower concentrations of $\mathrm{T} 3$ stimulate hemin-induced hemoglobin production, while a higher concentration of T3 abolishes this effect. Changes in CD71 and $\alpha$-globin mRNA expression with various concentrations of T3 during hemin-induced erythropoiesis were consistent with the changes in hemoglobin production. However, the benzidine-positive rate 


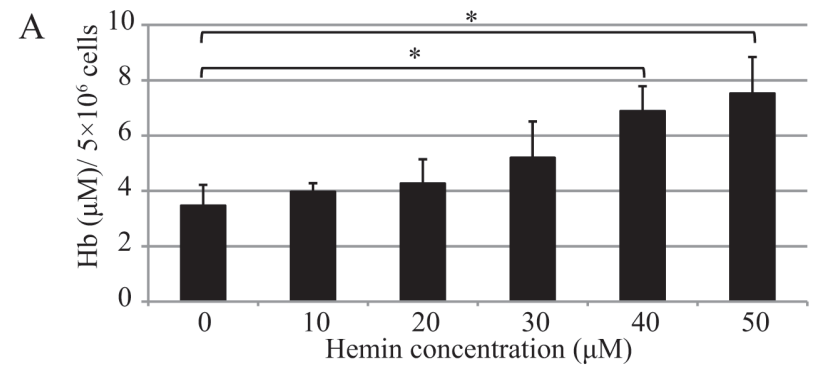

B (1) GATA1

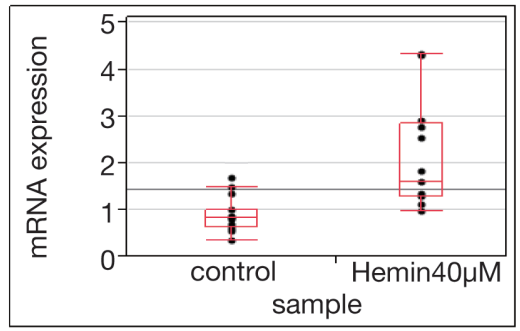

(3) NFE2

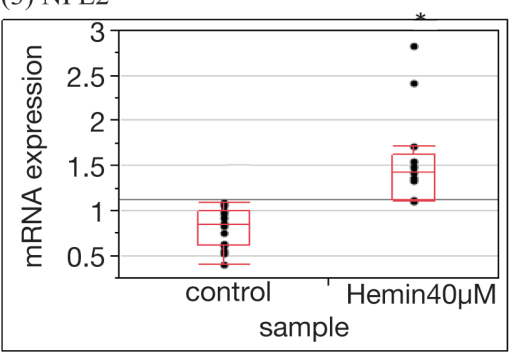

(5) $\beta$-globin

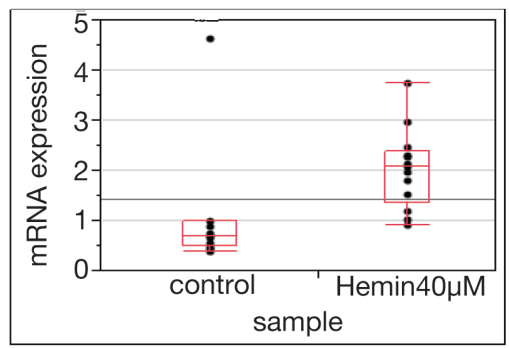

(7) $\mathrm{TR} \alpha$

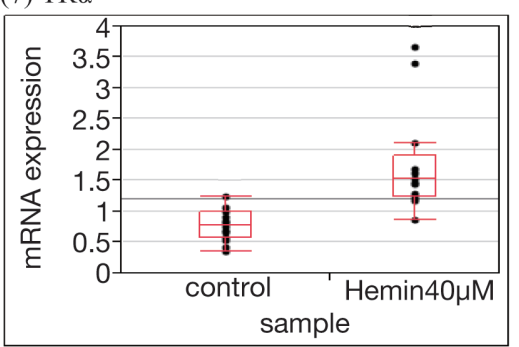

(2) GATA2

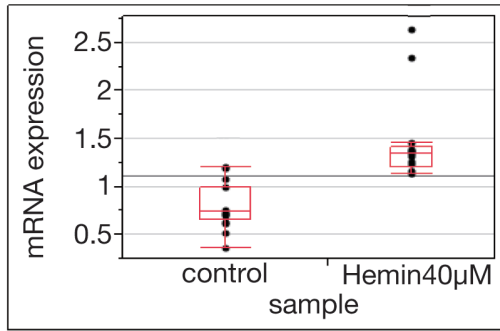

(4) $\alpha$-globin

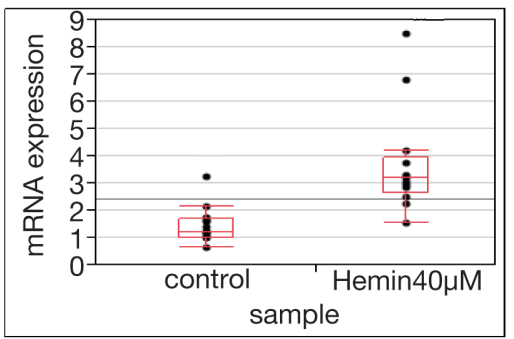

(6) $\operatorname{RXR} \alpha$

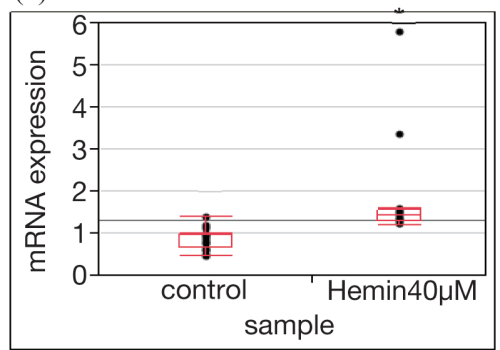

(8) TR $\beta$

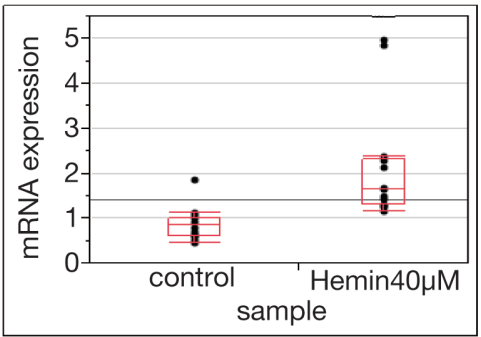

Fig. 2 Changes in K562 cells after exposure to hemin.

(A) Hemoglobin content increased in a dose-dependent manner after exposure to various concentrations of hemin for $72 \mathrm{~h}$. Experiments were performed in triplicate in different dishes. ${ }^{*} p<0.05$ by Kruskal-Wallis test. (B) Changes in mRNA expression in K562 cells during hemin-induced erythropoiesis were measured for transcription factors related to erythropoiesis (B-1: GATA1, B-2: GATA2, B-3: NFE2, B-4: $\alpha$-globin, B-5: $\beta$-globin) and for thyroid hormone receptors (B-7: TR $\alpha$, B-8: TR $\beta$ ) and retinoid $\mathrm{X}$ receptor $(\mathrm{B}-6: \mathrm{RXR} \alpha)$. Each relative mRNA level was normalized based on the level for PPIA. Differences in mRNA levels between control and hemin-treated cells were analyzed by Mann-Whitney U test ( ${ }^{*} p<0.05$, hemin: $n=13$, control: $\left.n=16\right)$. Hemin treatment was performed at $40 \mu \mathrm{M}$ for $48 \mathrm{~h}$. 
Table 1 Cell proliferation and cell viability of K562 cells in the presence or absence of hemin at each indicated time point.

\begin{tabular}{lcccc} 
& Calculated time point & Hemin(-) & Hemin $(+)$ & \\
\hline $\begin{array}{l}\text { Cell count } \\
\left(\times 10^{5} / \mathrm{mL}\right)\end{array}$ & 0 hour & \multicolumn{2}{c}{2} & \\
\hline $\begin{array}{l}\text { Cell viability } \\
(\%)\end{array}$ & 72 hours & $13.7 \pm 2.24$ & $6.72 \pm 1.89$ & $p<0.05$ \\
\hline
\end{tabular}

Significance was analyzed by Mann-Whitney U test. Experiments were performed four times in individual cell cultures.

Table 2 FACS analysis of CD71 and CD235a expression with or without hemin treatment.

\begin{tabular}{ccccc} 
& & Hemin(-) & Hemin $(+)$ & \\
\multirow{2}{*}{ CD71 } & MFI & $2.624 \pm 0.617$ & $4.836 \pm 1.755$ & $p<0.05$ \\
& Positive rate (\%) & $32.7 \pm 2.12$ & $62.0 \pm 1.72$ & $p<0.05$ \\
\hline \multirow{2}{*}{ CD235a } & MFI & $0.334 \pm 0.017$ & $0.851 \pm 0.701$ & N.S. \\
& Positive rate (\%) & $3.25 \pm 2.94$ & $1.35 \pm 0.48$ & N.S. \\
\hline
\end{tabular}

CD71 (transferrin receptor) and CD235a (glycophorin A) were analyzed after exposure of K562 cells to hemin for $72 \mathrm{~h}$. Expression levels are given as the mean fluorescence intensity $(\mathrm{MFI})($ mean $\pm \mathrm{SD})$ and positive rate $($ mean $\pm \mathrm{SD}, \%)$. Five samples in different dishes were measured. Significance was analyzed by Mann-Whitney U test.

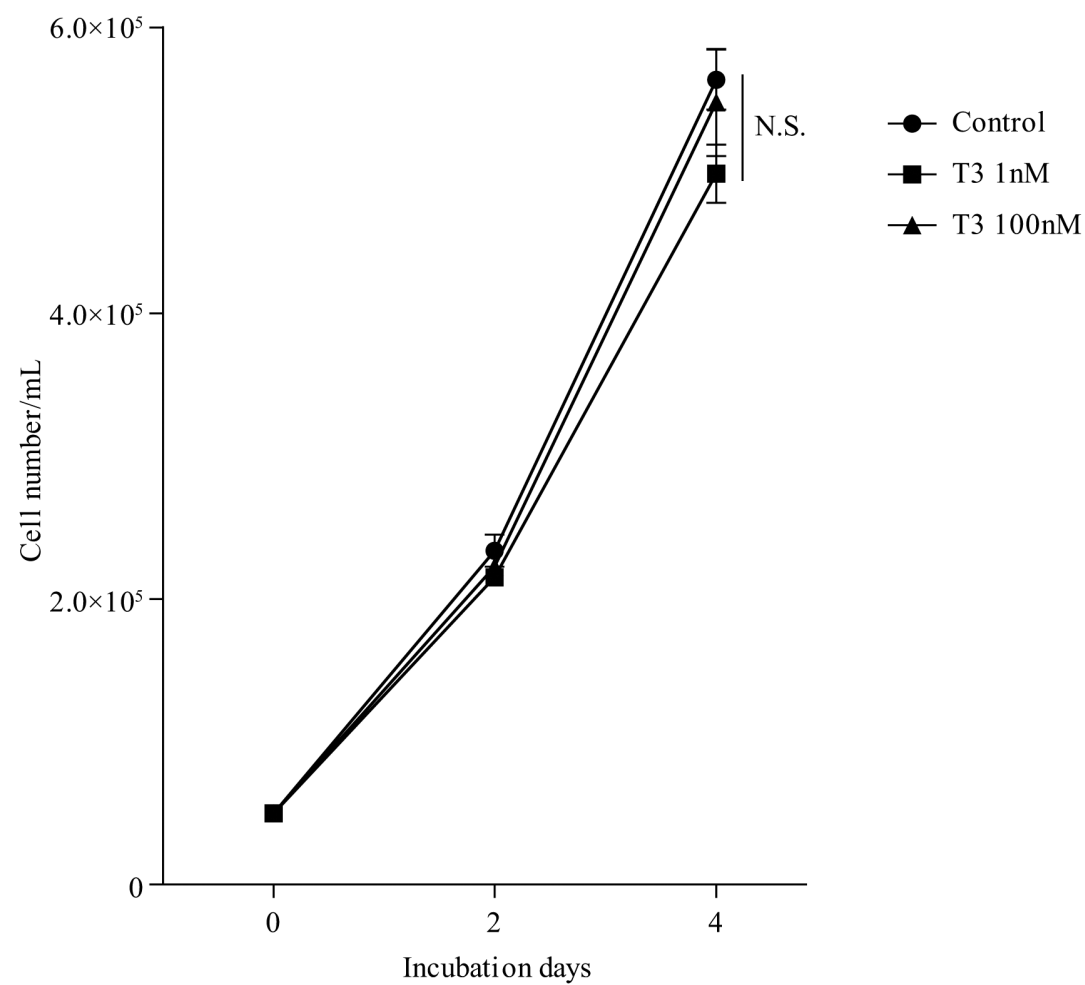

Fig. 3 Cell proliferation analysis in K562 cells in the presence or absence of hemin.

Viable cell numbers in the indicated culture condition were calculated. T3 at $1 \mathrm{nM}$ and $100 \mathrm{nM}$ did not alter cell proliferation up to four days. ${ }^{*} p<0.05$ by Kruskal-Wallis test. Experiments were performed four times. 
$\mathrm{A}(1)$

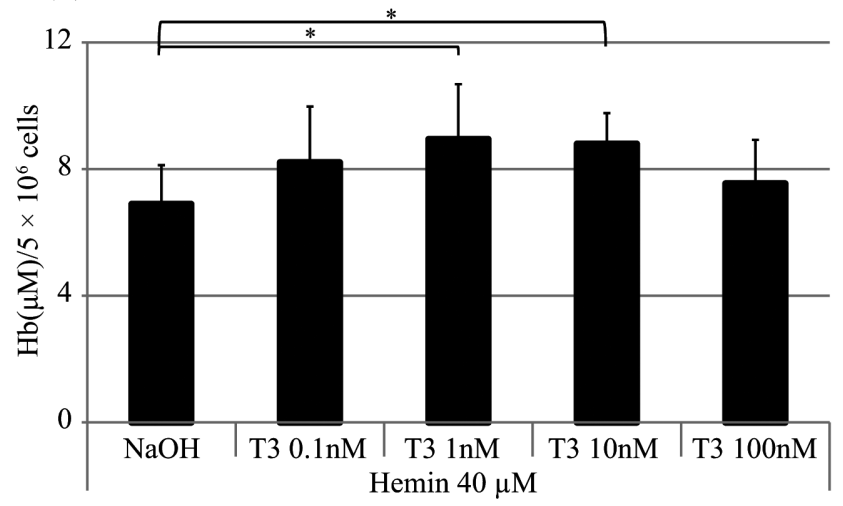

A (3)

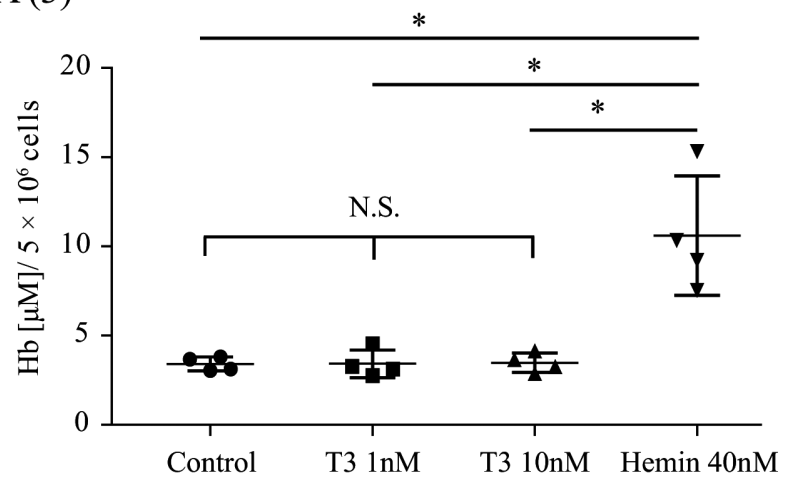

A (2)

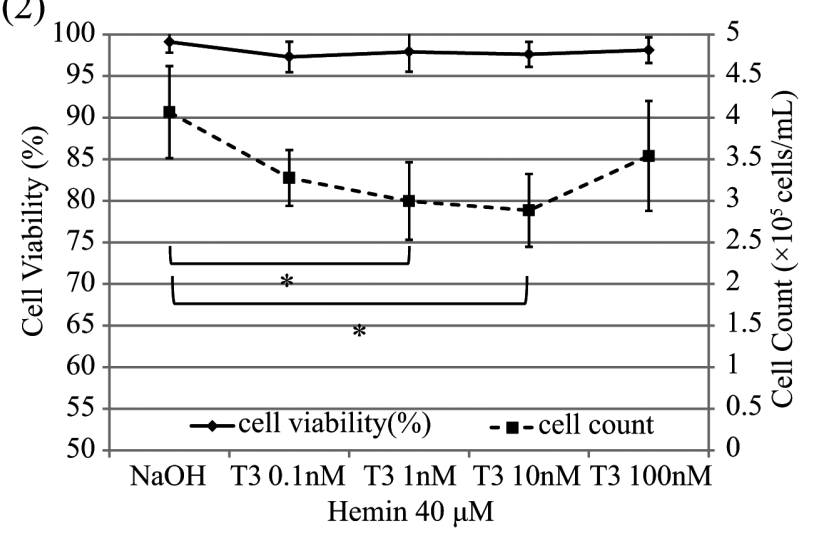

B

B $\square$ CD71 MFI -CD71 positive rate (\%)

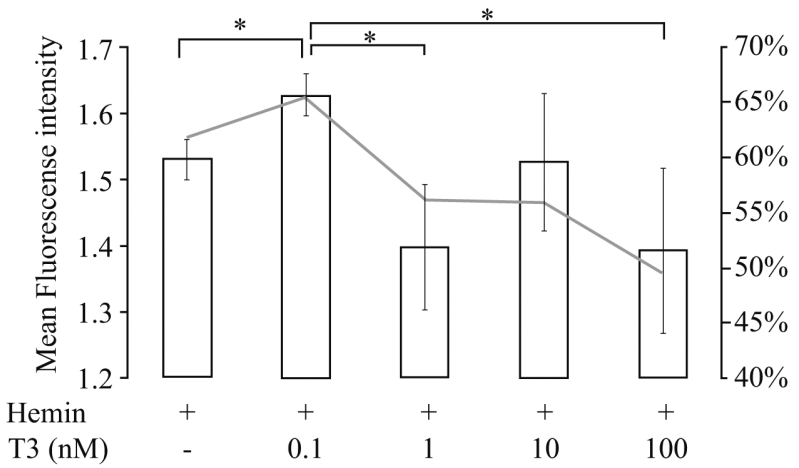

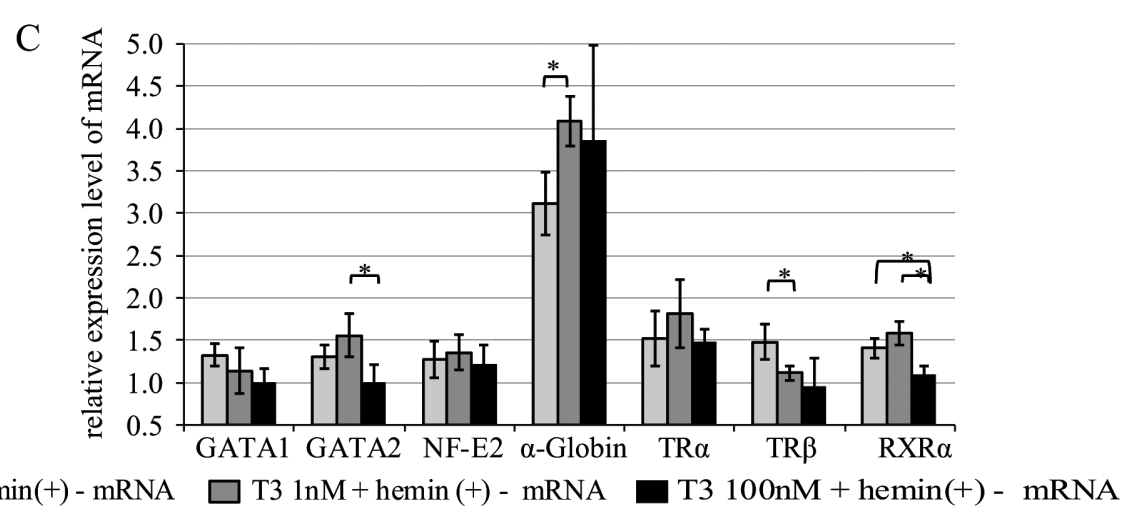

Fig. 4 Effects of $\mathrm{T} 3$ on parameters of hemin-induced erythropoiesis.

(A-1) Hemoglobin production per $5 \times 10^{6}$ cells. K562 cells were incubated with various concentration of T3 for 24 h prior to hemin exposure and then counted and measured. Pre-incubation with 1 or $10 \mathrm{nM}$ T3 significantly enhanced hemin-induced hemoglobin production compared to hemin-treated cells without T3 pre-incubation. ${ }^{*} p<0.05$ by Kruskal-Wallis test $(n=10)$. Experiments were performed in different cultures. Hemin treatment was performed at $40 \mu \mathrm{M}$ for $72 \mathrm{~h}$. (A-2) Cell counts and viabilities in the A-1 cultures. The numbers of viable cells and cell viability in the indicated A-1 culture were calculated with an automated cell counter using trypan blue exclusion. (A-3) Hemoglobin content per $5 \times 10^{6}$ cells. K562 cells were incubated with various concentration of T3 for $24 \mathrm{~h}$ and then counted and measured. Pre-incubation with 1 or $10 \mathrm{nM}$ T3 did not alter hemoglobin production compared to control (no treatment). ${ }^{*} p<0.05$ by Kruskal-Wallis test (each $\left.n=4\right)$. Experiments were performed in different cultures. Hemin treatment (positive control) was performed at $40 \mu \mathrm{M}$ for $72 \mathrm{~h}$. (B) FACS analysis of CD71 expression. Incubation with 0-100 $\mathrm{nM} \mathrm{T3}$ for $24 \mathrm{~h}$ prior to hemin treatment showed biphasic effects on MFI and the CD71-positive rate. Error bars for MFI show mean \pm SD (each $n=5$ ). ${ }^{*} p<0.05$ by Kruskal-Wallis test. Hemin treatment was performed at $40 \mu \mathrm{M}$ for $72 \mathrm{~h}$. (C) mRNA expression. Cells were cultured with 0,1 or $100 \mathrm{nM} \mathrm{T} 3$ for $24 \mathrm{~h}$ prior to hemin exposure. Hemin treatment was performed at $40 \mu \mathrm{M}$ for $48 \mathrm{~h}$. Each mRNA was normalized using the level for PPIA. Calibration of hemin (-) mRNA was set in one sample at 0 days. Transcription factors related to erythropoiesis (GATA2, NFE2, $\alpha$-globin) and thyroid hormone receptors $(\mathrm{TR} \alpha, \mathrm{TR} \beta)$ and the partner retinoid $\mathrm{X}$ receptor $\alpha(\mathrm{RXR} \alpha)$ were measured. $* p<0.05$ by Kruskal-Wallis test $(n=7)$. 
did not differ between T3-pretreated and control cells after hemin induction. This is probably because benzidine positivity with hemin treatment may be affected by free hemin diffusing into the cells, which may cause misleading results $[25,29]$. Overall, these findings indicate that $\mathrm{T} 3$ at a lower concentration acts as an enhancer of hemin and that $100 \mathrm{nM} \mathrm{T3}$ blocks this effect in our model of erythroid differentiation.

A biphasic action of T3 has been reported in colony growth of K562 cells and proliferation of erythroid burst forming units (BFU-Es) in human peripheral blood and bone marrow mononuclear cells in serum free culture [30, 31]. A recent report showed that exposure of human hematopoietic progenitor cells to higher or lower than the normal concentration of thyroid hormone had a significant influence on clonogenicity and induced apoptosis [32]. Moreover, strong inhibition of terminal differentiation by $\mathrm{T} 3$ has been reported in Epo responsive NFS-60 cells [33] and we previously showed that T3 suppresses activin-induced K562 differentiation [19]. Hematopoietic progenitor cells obtained from hyperthyroid patients exhibit increased proliferative potential of BFU-Es and upregulation of cell cycle markers, compared to those from healthy volunteers [34]. These studies suggest that T3 exerts classical augmentation, but also has a suppressive effect on erythropoiesis, especially at a high concentration. These different responses to T3 could be due to 'stage-specific effects' of T3 on proliferation or differentiation, as proposed by Ingley et al., in which T3 stimulates proliferation of immature erythroid cells and inhibits maturation promoted by Epo $[35,36]$. Our findings of blockage of enhancement of erythropoiesis by $100 \mathrm{nM} \mathrm{T} 3$ in hemin-induced K562 cells without a toxic effect may reflect the action of $\mathrm{T} 3$ on hemoglobin synthesis because hemin is a strong inducer of heme biosynthesis. Regarding the relationship between thyrotoxicosis and erythropoiesis, clinical reports showing that erythroid hyperplasia occurs in hyperthyroidism have not accounted for the level of hyperthyroidism [5]. Treatment of hyperthyroidism has also been found to restore hemoglobin levels in GD with anemia [6].

Hemin induced increases in GATA1, GATA2, NFE2 mRNA levels in K562 cells, along with $\alpha$-globin and $\beta$-globin upregulation. GATA1 is highly expressed in erythroid cells and regulates expression of many erythroid genes, including genes for globins and heme synthesis enzymes [37-39]. GATA2 is usually expressed in early erythroid precursors and determines cell lin- eage throughout hematopoiesis, before being downregulated in the final stage of erythropoiesis $[37,40]$. NFE2, which regulates erythroid maturation and differentiation, is required for activation of the locus control region of the globin gene cluster during erythroid cell differentiation [41]. The increased GATA1 and NFE2 levels induced by hemin in K562 cells are in accord with previous findings[26], but the significance of GATA2 elevation after hemin exposure in K562 cells is unclear.

T3 at $100 \mathrm{nM}$ significantly decreased GATA2 mRNA expression compared to $1 \mathrm{nM} \mathrm{T3}$ in hemin-induced K562 cells, suggesting an association of GATA2 mRNA and T3 during erythropoiesis [19]. Expression of RXR $\alpha$ mRNA in cells treated with $100 \mathrm{nM}$ T3 was also decreased compared to that with $1 \mathrm{nM}$ T3 in hemin-induced K562 cells. A further study is needed to explore the roles of GATA2 and RXR $\alpha$ in T3 action during erythropoiesis. Our results also provide the first evidence for upregulation of $\operatorname{TR} \alpha, \operatorname{TR} \beta$, and $\operatorname{RXR} \alpha$ mRNA in hemin-treated K562 cells. There has been no previous report of thyroid hormone receptor upregulation during erythroid differentiation.

A major limitation of the study is that the effects of T3 on erythropoiesis were detected using a single model based on hemin-treated K562 cells. To confirm the basic effect of T3 on erythropoiesis, further studies using different cell lines and different erythropoietic agents are needed. Similarly, upregulation of TRs during erythropoiesis was only detected in hemin-treated K562 cells, and a further study is required to determine how TRs are related to erythropoiesis. A second limitation is that there are no single parameter showed upregulation at a low concentration of T3 and downregulation at a high concentration of T3. Hemoglobin production with various concentrations of $\mathrm{T} 3$ was closely related to reduced cell proliferation in our culture system, and cell cycle-regulated mRNAs have been reported to change during hemin-induced erythropoiesis [42]. Therefore, transcription factors related to the cell cycle may be candidates for exploration in a further study of the underlying mechanism.

\section{Conclusion}

We conclude that a higher concentration of T3 attenuates the stimulatory effect on hemin-induced erythroid differentiation without exerting a toxic effect in K562 cells. This conclusion is compatible with the well- 
known association between thyroid hormone and $\mathrm{Hb}$ levels in euthyroid to thyrotoxic GD patients. TR $\alpha, \operatorname{TR} \beta$ and RXR $\alpha$ mRNAs were induced by hemin and GATA2 and RXR $\alpha$ mRNA were altered synchronously with various concentrations of T3 during hemin-induced differentiation, suggesting the importance of these factors in this T3 activity in hemin-treated K562 cells.

\section{Acknowledgements}

The authors thank Dr. Kaori Endo-Umeda of
Nihon University School of Medicine (Tokyo, Japan) for technical assistance and helpful comments. We are also grateful to Maki Uenoyama (Division of Environmental Medicine, National Defense Medical College Research Institute) for her help with the experimental procedures.

\section{Disclosure}

None of the authors have any potential conflicts of interest associated with this research.

\section{References}

1. Chute JP, Ross JR, McDonnell DP (2010) Minireview: Nuclear receptors, hematopoiesis, and stem cells. Mol Endocrinol 24: 1-10.

2. Popovic WJ, Brown JE, Adamson JW (1977) The influence of thyroid hormones on in vitro erythropoiesis. Mediation by a receptor with beta adrenergic properties. J Clin Invest 60: 907-913.

3. Fein HG, Rivlin RS (1975) Anemia in thyroid diseases. Med Clin North Am 59: 1133-1145.

4. Ford HC, Carter JM (1988) The haematology of hyperthyroidism: abnormalities of erythrocytes, leucocytes, thrombocytes and haemostasis. Postgrad Med J 64: 735-742.

5. Das KC, Mukherjee M, Sarkar TK, Dash RJ, Rastogi GK (1975) Erythropoiesis and erythropoietin in hypoand hyperthyroidism. J Clin Endocrinol Metab 40: 211220.

6. Gianoukakis AG, Leigh MJ, Richards P, Christenson PD, Hakimian A, et al. (2009) Characterization of the anaemia associated with Graves' disease. Clin Endocrinol 70:781-787.

7. Perlman JA, Sternthal PM (1983) Effect of 131I on the anemia of hyperthyroidism. J Chronic Dis 36: 405-412.

8. Rivlin RS, Wagner HN Jr (1969) Anemia in Hyperthyroidism. Ann Intern Med 70: 507-516.

9. Malgor LA, Blanc CC, Klainer E, Irizar SE, Torales PR, et al. (1975) Direct effects of thyroid hormones on bone marrow erythroid cells of rats. Blood 45: 671-679.

10. Kendrick TS, Payne CJ, Epis MR, Schneider JR, Leedman PJ, et al. (2008) Erythroid defects in TRalpha ${ }^{-/-}$ mice. Blood 111: 3245-3248.

11. Bauer a, Mikulits W, Lagger G, Stengl G, Brosch G, et al. (1998) The thyroid hormone receptor functions as a ligand-operated developmental switch between proliferation and differentiation of erythroid progenitors. EMBO J 17: 4291-4303.

12. Lozzio CB, Lozzio BB (1975) Human chronic myelogenous leukemia cell-line with positive Philadelphia chromosome. Blood 45: 321-334

13. Hoffman R, Murnane MJ, Benz EJ Jr, Prohaska R, Floyd V, et al. (1979) Induction of erythropoietic colonies in a human chronic myelogenous leukemia cell line. Blood 54: 1182-1187.

14. Horton MA, Cedar SH, Edwards PAW (1981) Expression of Red Cell Specific Determinants during Differentiation in the K562 Erythroleukaemia Cell Line. Scand J Haematol 27: 231-240.

15. Koeffler HP, Golde DW (1980) Human myeloid leukemia cell lines: a review. Blood 56: 344-350.

16. Nakamichi I, Habtezion A, Zhong B, Contag $\mathrm{CH}$, Butcher EC, et al. (2005) Hemin-activated macrophages home to the pancreas and protect from acute pancreatitis via heme oxygenase-1 induction. J Clin Invest 115: 3007-3014.

17. Tonkonow BL, Hoffman R, Burger D, Elder JT, Mazur EM, et al. (1982) Differing responses of globin and glycophorin gene expression to hemin in the human leukemia cell line K562. Blood 59: 738-746.

18. Iwasaki K, Mackenzie EL, Hailemariam K, Sakamoto K, Tsuji Y (2006) Hemin-mediated regulation of an antioxidant-responsive element of the human ferritin $\mathrm{H}$ gene and role of Ref-1 during erythroid differentiation of K562 cells. Mol Cell Biol 26: 2845-2856.

19. Yamamoto Y, Shiraishi M, Fujita M, Kojima I, Tanaka Y, et al. (2014) Triiodothyronine suppresses activininduced differentiation of erythroleukemia K562 cells under hypoxic conditions. Mol Cell Biochem 391: 217224.

20. Thompson CC, Evans RM (1989) Trans-activation by thyroid hormone receptors: functional parallels with steroid hormone receptors. Proc Natl Acad Sci U S A 86:3494-3498.

21. Cheng SY, Leonard JL, Davis PJ (2010) Molecular aspects of thyroid hormone actions. Endocr Rev 31:139-170.

22. Rowley PT, Ohlsson-Wilhelm BM, Farley BA, LaBella 
S (1981) Inducers of erythroid differentiation in K562 human leukemia cells. Exp Hematol 9: 32-37.

23. Baliga BS, Mankad M, Shah AK, Mankad VN (1993) Mechanism of differentiation of human erythroleukaemic cell line K562 by hemin. Cell Prolif 26: 519-529.

24. Kawasaki N, Morimoto K, Tanimoto T, Hayakawa T (1996) Control of hemoglobin synthesis in erythroid differentiating K562 cells. I. Role of iron in erythroid cell heme synthesis. Arch Biochem Biophys 328: 289294.

25. Sztiller-Sikorska M, Jakubowska J, Wozniak M, Stasiak M, Czyz M (2009) A non-apoptotic function of caspase-3 in pharmacologically-induced differentiation of K562 cells. Br J Pharmacol 157: 1451-1462.

26. Wu XR, Xue M, Li XF, Wang Y, Wang J, et al. (2011) Phenolic metabolites of benzene inhibited the erythroid differentiation of K562 cells. Toxicol Lett 203: 190199.

27. Fathallah H, Portnoy G, Atweh GF (2008) Epigenetic analysis of the human alpha- and beta-globin gene clusters. Blood Cells Mol Dis 40: 166-173.

28. Miller CW, Young K, Dumenil D, Alter BP, Schofield JM, et al. (1984) Specific globin mRNAs in human erythroleukemia (K562) cells. Blood 63: 195-200.

29. Cioe L, McNab A, Hubbell HR, Meo P, Curtis P, et al. (1981) Differential expression of the globin genes in human leukemia K562(S) cells induced to differentiate by hemin or butyric acid. Cancer Res 41: 237-243.

30. DainiakN, SutterD, KreczkoS(1986)L-triiodothyronine augments erythropoietic growth factor release from peripheral blood and bone marrow leukocytes. Blood 68: 1289-1297.

31. Gauwerky C, Golde DW (1980) Hormonal effects on cell proliferation in a human erythroleukemia cell line (K562). Blood 56: 886-891.

32. Grymuła K, Paczkowska E, Dziedziejko V, BaśkiewiczMasiuk M, Kawa M, et al. (2007) The influence of 3,3',5-triiodo-L-thyronine on human haematopoiesis. Cell Prolif 40: 302-315.
33. Perrin MC, Blanchet JP, Mouchiroud G (1997) Modulation of human and mouse erythropoiesis by thyroid hormone and retinoic acid: evidence for specific effects at different steps of the erythroid pathway. Hematol Cell Ther 39: 19-26.

34. Kawa MP, Grymula K, Paczkowska E, BaskiewiczMasiuk M, Dabkowska E, et al. (2010) Clinical relevance of thyroid dysfunction in human haematopoiesis: biochemical and molecular studies. Eur J Endocrinol 162: 295-305.

35. Ingley E, Tilbrook PA, Klinken SP (2004) New insights into the regulation of erythroid cells. IUBMB Life 56: 177-184.

36. Ingley E, Chappell D, Poon SY, Sarna MK, Beaumont JG, et al. (2001) Thyroid hormone receptor-interacting protein 1 modulates cytokine and nuclear hormone signaling in erythroid cells. J Biol Chem 276: 4342843434.

37. Ferreira R, Ohneda K, Yamamoto M, Philipsen S (2005) GATA1 function, a paradigm for transcription factors in hematopoiesis. Mol Cell Biol 25: 1215-1227.

38. Trainor CD, Evans T, Felsenfeld G (1995) Negative regulation of chicken GATA-1 promoter activity mediated by a hormone response element. Mol Endocrinol 9: 1135-1146.

39. Yu HC, Zhao HL, Wu ZK, Zhang JW (2011) Eos negatively regulates human $\gamma$-globin gene transcription during erythroid differentiation. PLoS One 6: e22907.

40. Bresnick EH, Lee HY, Fujiwara T, Johnson KD, Keles S (2010) GATA switches as developmental drivers. J Biol Chem 285: 31087-31093.

41. Andrews NC, Erdjument-Bromage H, Davidson MB, Tempst P, Orkin SH (1993) Erythroid transcription factor NF-E2 is a haematopoietic-specific basic-leucine zipper protein. Nature 362: 722-728.

42. Tsiftsoglou AS, Pappas IS, Vizirianakis IS (2003) Mechanisms involved in the induced differentiation of leukemia cells. Pharmacol Ther 100: 257-290. 